PROBLEMS

OF MANAGEMENT

IN THE $21{ }^{\text {st }}$ CENTURY

Vol. 12, No. 1, 2017

4

\section{AN UNHEARD CALL FOR BRIDGING ETHICS AND GOVERNANCE: SAVE THE PLANET}

The awakening call of the twenty first century is to bring discipline in corporate behavior and attitude. The global financial crisis that gallops the whole economic system posits an unbeatable challenge before the society and demands a careful revisit of corporate routine to revamp trust and confidence on corporate affairs. Capitalism has accepted its inability to drag down the voluminous attitude of people who live in professional edge and isolate themselves from the mass on the ground of their superiority in terms of power, skill, and trust. Then the president of US had acknowledged that this was the biggest crisis that US economy faced after the 1929 stock market debacle. That crisis resulted stringent regulations to control Wall Street which is the Securities Act 1933 and the Securities Exchange Act 1934. This crisis also results Sarbanes Oxley Act 2002. Both of these two events have good similarities, sanctioning too much freedom and independence, capsizing the market gaps, destroying the whole system and confidence, and finally facing the rude destiny.

Ethics and ethical guidelines are very much rudimentary in corporate affairs. Initially, it was a mental state which one needs to believe, trust, cultivate and practice. The society keeps its eternal journey capitalizing the practice of ethics over the years. When ethics gets its way to corporate world, it is confined into a definition in the form of codes of ethics. The question is whether the word 'ethics' is so narrow that it can be defined as a code. However, it becomes a broader guideline and firms have started a competition to encrypt the ethical values in the corporate motto, vision and mission statements. It becomes more fashion than something to believe and practice. It is really a choice between comply or compromise. The reason of such criticism is very apparent. When you find a checklist to comply, you will try to do the minimum and slip in edges.

In every professional credentials, compliance on some particular code of ethics is made mandatory. For example, Institute of Management Accountants (IMA) has considered four broader standards, namely, competence, confidentiality, integrity and credibility. Fundamental principles of International Federation of Accountants (IFAC) code of ethics includes integrity, objectivity, professional competence and due care, confidentiality, and professional behavior which has been copied by world premier professional accounting institutes like Chartered Institute of Management Accountants (CIMA), Institute of Chartered Accountants of England and Wales (ICAEW) etc. In all of these cases, one of the most important principles is integrity which demands a certain mental maturity and behavior in addition to skill and other requirements relating to the particular profession. Though the integrity requirements are properly taken care of, where does the problem lay that induces a vested quarter to look after their personal interest? There is a problem in the thought process of ethical movement within the society.

Can ethics be taught? At some point in life, ethics must be taught. People are not born with innate desires to be ethical or to be concerned with the welfare of others. The role of the family includes teaching children a code of ethical behavior that includes respect for parents, siblings, and others. The family bears chief responsibility for ensuring that children will receive the necessary education and moral guidance to become productive members of society. The 
basic values such as honesty, self-control, concern for others, respect for legitimate authority, fidelity, and civility must be passed from one generation to the next, a fundamental process of the family. A 1990 article in the Wall Street Journal reported the results of a Gallup Poll that found 84 percent of public school parents want moral values taught in school and 68 percent want educators to develop strict standards of "right and wrong." As a result of parental pressure, some state legislatures and education departments are urging public schools to teach students values such as honesty, respect, and patriotism. Hundreds of business firms, such as Digital Equipment Corp. of Maynard, Massachusetts and Glendale Federal Bank of Glendale, California, have provided millions of dollars for such programs (Nazario, 1990).

Due to the outburst of unethical activities of some unscrupulous white-collar executives where power is exercised seriously to build monarchy of fortune by few peoples at the cost of millions, the whole world has witnessed serious regulatory attempts to chalk out a feasible solution which has successfully attracted the attention of bigger community in the name 'Governance'. UK Corporate governance code prescribes five main principles of governance, namely, leadership, effectiveness, accountability, remuneration, and relations with shareholders. Every country has developed its own code of corporate governance. It is really a big concern that the corporate managers are working for the interest of all the stakeholders without any biased attitude. Different models captured the particular philosophy which demonstrates the economic and political structure which is applicable to that particular statute.

The governance structure initially was a response against agency theory, where a solution is sought for any quasi objective of management that is not supportive to the objective of shareholders or owners and vice versa. Then other theories like stakeholders' theory, stewardship theory, transaction cost theory, resource dependency theory and principal cost theory have also been addressed to design corporate governance structure in different countries. This movement is just to make the concept of corporate governance more external than internal. If it concentrates on the value maximization of internal groups only, governance is not in practice. Due to the same reasons, the models of corporate governance have been refined seriously in different parts of the world.

The Anglo-American model was a single tire model which is primarily designed under agency theory to protect the interest of the owners, particularly, shareholders. To make it more general the German Model and Japanese Model proposes two tire systems where the board is more representative and accountable. Even in Japanese Model major banks play a significant role. These models are also under severe criticism and are under modification process. The modification requirements are due to the revised definitions of corporate governance. Throughout the whole process, the only consideration is restoration of public confidence and trust on corporate management. The misuse of power resulted the crisis which gives birth to the concept of corporate governance as a regulatory intervention through SOX 2002. The framework of Public Company Accounting Oversight Board (PCAOB) as proposed in SOX 2002 has been copied grossly in essence by regulators in different countries. It signifies the regulatory urgency of corporate governance requirements. However, the missing line is the unseen gap between ethics and governance. We must not forget ethics in defining corporate governance though governance is the corporatized version of ethics, the constructivist epistemological paradigm.

A recent study of IFAC discloses that a larger number of professional accountants in the workforce correlate to a better ranking in Transparency International corruption perception index. This correlation is up to three times stronger in G20, according to the study. In this regard, IFAC CEO Fayez Choudhury said, "The accountancy profession is a crucial part of strong national governance architectures that confront corruption, in partnership with good government and strong businesses. And vitally, the study shows professional ethics, education, and oversight, at the core of the global accountancy profession, are key to the profession's positive impact in tackling corruption." 
Nikhil Chandra SHIL. An unheard call for bridging ethics and governance: Save the planet

PROBLEMS

OF MANAGEMENT

IN THE $21^{\text {st }}$ CENTURY Vol. 12, No. 1,2017

With this, this editorial draws the concluding remarks. Due to some severe corporate scandals witnessed at the beginning of this century, the whole world is fingering at the accounting profession, the elite class professionals in business. The question, 'who will audit the auditors?' gets legitimacy. At the same time, the IFAC, the only international regulator of accounting profession, announces the role of accountants to combat corruption. But the profession requires strong governance architectures embedded with ethics. This is the urgent call for regulators, academicians, practitioners, professionals and all to understand this hidden relationship which will help to restore public confidence on accounting and reporting, conserve world resources and ensure transparency and accountability framework for the greater benefit of the society.

\section{References}

Nazario, S. L. (1990). Schoolteachers say. Wall Street Journal, April 6, pp. B1, B6.

IFAC (2017). The accountancy profession - playing a positive role in tackling corruption, February.

Received: April 05, 2017

Accepted: June 18, 2017

Nikhil Chandra Shil

Assistant Professor, Department of Business Administration, East West

University, Dhaka, Bangladesh.

Email: nikhilacc@yahoo.com 